\title{
A Case Study of Honest Character Development in Early Childhood in Bengkulu City
}

\author{
Kimli Haroswinarti ${ }^{1, *}$, Rambat Nur Sasongko ${ }^{2}$, Muhammad Kristiawan ${ }^{3}$, Eca Gesang Mentari ${ }^{4}$ \\ ${ }^{1}$ Universitas Dehasen Bengkulu, Indonesia \\ ${ }^{2,3}$ Universitas Bengkulu, Indonesia \\ ${ }^{4}$ Institut Agama Islam An Nur, Indonesia \\ *kimliharoswinarti123@gmail.com
}

\begin{abstract}
The character gap is very dangerous and can occur if communication and hanging out together no longer exist in the community environment. This study aims to analyze the character development of honesty in early childhood group B PAUD Fatma Kenanga Bengkulu City. The descriptive qualitative type of survey was used as a research method, involving 21 children of group B PAUD Fatma Kenanga Bengkulu City in the 2016/2017 academic year. Data were collected through observations to measure the honesty character of children carried out by classroom and central teachers using a Likert scale, then analyzed using the average formula. The results of the study concluded that the development of honest character in PAUD group B PAUD Fatma Kenanga Bengkulu City had developed well, especially in the indicators of private property. Meanwhile, some other honest character developments show the behavior of children who are just starting to develop them. The implication of this research shows that the honest character of children makes children more independent and pious, therefore character education for children needs to be paid attention to so that the nation and state can advance.
\end{abstract}

Keyword: early childhood; character development; honest character

\section{Studi Kasus Perkembangan Karakter Jujur pada Anak Usia Dini di Kota Bengkulu}

\begin{abstract}
Abstrak
Kesenjangan karakter sangat berbahaya dan dapat terjadi jika komunikasi dan bergaul bersama tidak lagi ada dalam lingkungan masyarakat. Penelitian ini bertujuan menganalisis pengembangan karakter kejujuran pada anak usia dini kelompok B PAUD Fatma Kenanga Kota Bengkulu. Kualitatif deskriptif jenis survei digunakan sebagai metode penelitian, dengan melibatkan 21 anak kelompok B PAUD Fatma Kenanga Kota Bengkulu Tahun Pelajaran 2016/2017. Data dikumpulkan melalui observasi untuk mengukur karakter kejujuran anak yang dilakukan oleh guru kelas dan guru pusat menggunakan skala likert, seterusnya dianalisis menggunakan rumus ratarata. Hasil penelitian menyimpulkan bahwa perkembangan karakter jujur pada PAUD kelompok B PAUD Fatma Kenanga Kota Bengkulu telah berkembang dengan baik, telutama pada indikator private property. Sedangkan untuk beberapa perkembangan karakter jujur lainnya menunjukan perilaku anak baru mulai mengembangkannya. Implikasi penelitian ini menunjukan bahwa karakter jujur anak menjadikan anak lebih mandiri dan bertakwa, maka dari itu pendidikan karakter bagi anak perlu diperhatiakan agar bangsa dan negara dapat maju.
\end{abstract}

Kata Kunci: anak usia dini; perkembangan karakter; karakter jujur 


\section{INTRODUCTION}

Character is a psychological, moral, truth, goodness, strength or character that characterizes an individual or group so that it differentiates it from other individuals and groups that are manifested through action (Anggraini \& Kuswanto, 2019; Juanda, 2019; Setiawati, 2015; Yaumi, 2014). Character itself is a habit, temperament and character that forms individual self-awareness that needs to be instilled from an early age in the family, school or community environment (Sri Wening, 2012; Waryanti, 2015). Character has several pillars, is: respect, responsibility, awareness of citizenship, fairness and honesty, care and trust. Where with the presence of character, physical perfection in humans will look beautiful and more beautiful (Munawwaroh, 2019).

The character that becomes the reference as contained in the six pillars of character issued by the character count Coalition (a Project of The Josep Institute of Ethics). Six types of character that need to be possessed, is: 1) Trustworthiness, a form of character that makes individuals with integrity, honest, fair, and loyal; 2) Fairness, a form of character that makes individuals open minded and does not like to harm others; 3) Caring, the form of a person's character who has sympathy and empathy for humans and the environment; 4) Respect, a form of character that makes individuals respect and respect others; 5) Citizenship, a form of character who is aware of laws and regulations and cares for the environment; 6) Responsibility, a form of character that makes individuals responsible, disciplined, and tries their best (Silahuddin, 2017).

Schiller quotes (Yaumi, 2014) argues that a more purposeful life is obtained from the character of honesty that continues to be developed, the absence of honesty will have an impact on decreasing all the efforts made. Honesty in the nature of admitting, speaking and giving something in accordance with reality and truth (Batubara, 2015; Kesuma, 2011). The Directorate General of Non-formal and Informal Early Childhood Education (2012) states that being honest is a condition related to sincerity and sincerity to do right. Honest is a character that is formed from an attitude of trust. Amanah is honest and reliable in carrying out commitments, duties and obligations. Therefore, trustworthy or trustworthy means being honest (Yaumi, 2014). The character of honesty is included in the value of religious character which reflects faith and devotion to God Almighty, where with honesty the relationship between humans and God and human and other human relationships can be maintained properly (Komara, 2018). 
Character development cannot be separated from the goals of national education and requires the role of character education (Surya, 2017), where the foundation of education is to form human character as well as to create humans who have religious and cultural moral values. Humans with character balanced with strong intellectual and integrity will create an independent person, but on the other hand, if humans do not have positive characteristics, it will backfire on themselves and reduce the quality of morality in a country. The models, strategies and learning methods used can stimulate the development of children's character.

According to Kohlberg, moral or character education should be started early, this is a preventive effort so that later when they grow up they can control behavior that is in accordance with moral values (Tadjuddin, 2018). An environment with character will produce children with character as well, the nature of children who are born in a holy state can be optimized (Prasanti \& Fitrianti, 2018), This is related to the variety of environments that play a role in character development (school, family, friends and the media). Character education not only teaches what is right and what is wrong to children, but more than that character education instills habits (habituation) about the good until they understand, are able to feel and willing to implement it.

The declining moral quality at present shows that the importance of carrying out character education, schools are the main role in developing good character values for children (Burhanuddin, 2019; Fitri \& Na'imah, 2020), because of the essence of character education is the process of guiding children. Character education is an effort to help the development of a child's soul, both physically and spiritually, from their nature to a better human and civilization as well as instilling an honest character (Ernawati, 2017; Mulyasa, 2013), this agrees with Lickona (1991) which states that character education is an attempt to direct someone so that they can understand the values of good character. As the goal of character education, it is necessary to improve the quality of education so that children are more independent in adding and developing their knowledge which is manifested in everyday life (Mulyasa, 2013). In addition, character education in Islam aims to make humans always on the right and straight path, the path that has been outlined by Allah SWT and their actions reflect the values contained therein Al-Qur'an.

Ministry of National Education, Center for Research and Development of Curriculum and Bookkeeping (2011) Character education aims to develop the values that shape the character of the nation, is Pancasila, including: (1) developing the potential of students to 
have noble character, good minded people, and behave well; (2) building a nation characterized by Pancasila; (3) developing the potential of citizens to have a confident attitude, be proud of their nation and country, and love humanity. Character education in children depends on the education of their parents, if the parents educate them well, the children will be good, and vice versa. However, character education in children is not only the role of parents but also the role of the environment which has a big impact on children (Rochmawati, 2018).

A country that is difficult to rise from a critical condition as a result of a culture of corruption which is a practice of moral violations (dishonesty, irresponsibility, low discipline, low commitment to good values) (Megawangi, 2004). The PERC (Political and Economic Risk Consultancy) survey results show that Indonesia's ranking in the corruption score is the highest in Asia in the 2006 period with a score of 8.16 (out of a total score of 10), then data from Transparency International (2002 and 2006) Indonesia is included in Top 10 most corrupt in the world. The advancement of technology today is one of the factors that causes character values to be neglected. We see a lot of how children imitate their idols from watching on television as well as the number of applications that are actually less educational on cellphones, making it difficult for children to control their character values (Fauzi et al., 2013; Nurgiansah, 2021).

Observations made by researchers from 5 January 2015 to 9 January 2015 at PAUD Fatma Kenanga Bengkulu City regarding the development of the honest character of children, apparently there are still some who are not used to telling stories. In fact, they are not able to care for and look after school toys, children do not want to admit mistakes when making mistakes, children find it difficult to accept the superiority of others, children take things belonging to school.

Cultivating all the values of good character is very important and is the essence of character building that is needed today. Character building for children who are not yet perfect and who do not understand what is being taught must be done repeatedly, is; 1) teach and be an example; 2) teaches how to meet physiological needs and take care of oneself; 3 ) teach children to recognize their position at home, such as giving assignments and responsibilities; 4) provide freedom and direction to experiment; 5) rules are given consistently. 
Research on character in children has been carried out such as, character building through storytelling (Ramdhani et al., 2019), eleven effective principles in character education (Schaps \& Lewis, 2019), the role of teachers and parents in character building (Rochmawati, 2018), character development among adolescents (Lerner, 2018) and thematic learning in the formation of honest characters (Ramdhani \& Yuliastri, 2018). However, little research has been done on the development of honest character in children. In fact, in this study researchers will describe the development of the honest character of early childhood in PAUD Fatma Kenanga, Bengkulu City.

\section{RESEARCH METHOD}

The method used in this research is a descriptive qualitative method with the type of survey. Kerlinger argues, survey research is research conducted on large and small populations, but the data studied is data from samples taken from that population, to find the relative incidence, distribution, and relationship between sociological and psychological variables (Sugiyono, 2013). The research object was 21 class B children of Fatma Kenanga PAUD Bengkulu City.

Data collection was carried out by observation to measure the character of honesty in children, where the teacher gave his assessment according to the Likert scale size provided, after the data was collected, data analysis was carried out using the average formula on the measurement results of the Likert scale.

\section{RESULT AND DISCUSSION}

\section{A. Result}

Based on the results of the data obtained, the development of honest character in PAUD group B PAUD Fatma Kenanga Bengkulu City has developed well according to its age development. However, there are still some honest character developments that show the behavior that children are just starting to develop their honest character according to their age development.

From the results of the above research, there are several honest character developments on indicators that show high criteria from other honest character indicators, namely that children understand what private property and common property are and respect common property. In the indicator of honest character values, children understand which 
personal and collective assets are often included in the assessment criteria with an average score of 4 . This can be seen when the child arranges his shoes on the shoe rack that has been provided for him. Children differentiate between their friends and their own friends. Children have developed honest character which is good according to their age development.

Early childhood do not understand the concept of ownership, so they do not understand what is theirs and what is owned by others. With a mindset that is still concretely functional and its egocentric nature, children will think of themselves as the center of attention and claim everything is theirs. So, children must be taught to empathize with their friends regarding the concept of asking permission before borrowing and lending toys. The results showed that the strategy for developing honest children's character needs to be improved, so that children can understand the meaning of the concept of ownership and speak honestly when destroying or removing borrowed items from friends, even though their egocentric nature is still high.

The honest character of group B PAUD Fatma Kenanga children in Bengkulu City in appreciating collective property shows that the child has developed well according to their age development. Examples that can be taken are taking turns using tap water during ablution and washing hands, taking turns using colored pencils, taking enough toothpaste. At the toddler stage, playing is a form of playing media for children. When children play, conflicts often occur with their friends because of fighting over toys. Children can appreciate common property because the teacher also always provides an understanding of feelings of empathy and the impact that occurs due to not being able to appreciate common property.

Honest character in children there are also indicators that show low results with the criteria sometimes, namely willingness to admit mistakes, and appreciate the excellence of others. The development of honest character on the indicators of admitting mistakes in group B PAUD Fatma Kenanga Bengkulu City shows that new children begin to develop based on age development. children often feel afraid when they will express their honesty to the teacher, then the way the teacher does is to approach him, invite the child to talk as best as possible so that the child feels comfortable and finishes or gives him support so that he is not afraid and the problem is resolved.

Development of honest character values in indicators of appreciating people's excellence another in group B PAUD Fatma Kenanga shows that children are just starting to develop. the child is still not able to accept the superiority or victory of his friend, the child 
still has a silent expression or even cries if he cannot be like his friend. The indicator of honest character has shown clearly that the development of the honest character of children in group B PAUD Fatma Kenanga develops well and is according to their age. Honest character in Fatma Kenanga PAUD is taught using various learning methods that can be used by teachers and parents as guidelines, such as: habituation and exemplary. The methods and strategies used by PAUD Fatma Kenanga teachers are always evaluated by the teacher, so that deficiencies or even mistakes in providing learning can be corrected and optimized. the media in assisting the application of methods and strategies is always modified creatively and innovatively

This study also found that the importance of the role of parents, teachers and the environment in developing honest character in children, scolding and even hitting children will have an impact on this character, because children do not dare to reveal good mistakes, problems or feelings in the future. The development of children's character, especially honesty, requires support and examples from various parties, if we show our honesty children will imitate it. the child is an accomplished copycat who has the potential to become a habit. conveying the results of development to parents is carried out by the school, this is important so that parents know the character development in children, so that parents can improve their educational process or even provide teachers with solutions and ideas in developing children's character.

\section{B. Discussion}

Character development, especially honesty, can increase children's positive values in conveying something according to facts, so that other people's trust in the individual can be built. The higher a person's trust, the better the quality of honesty that is done. This is important so that children can make decisions about the actions they take (Purwanti, 2017). A lot of literature reveals that the character development of children in Indonesia (Burhanuddin, 2019; Purwanti, 2017; Surya, 2017) is still lacking so that better character education is needed. Even though character formation in children must begin to be formed when the child is still in the family environment (Prasanti \& Fitrianti, 2018).

Characters that are described as traits that have positive values are seen inherently (Wagner, 2019), as well as their similarities to the morals that govern the lives of individuals or more precisely virtuous (Davidson, 2010; Kim et al., 2019; Sayer et al., 2018; Wang et al., 2015; Zigon, 2007). In addition, important characters for children to use their creative 
abilities (Rudyanto, 2016), therefore the development of character values, especially honesty, is very important to stimulate and instill from an early age, so that children can build obedience related to the character of akhlakul karimah to Allah and guided by the prophet Muhammad by imitating his character and nature (Setyaningrum, 2017). This is because one of the objectives of the development of education is to create devout people and have good morals (Anwar, 2016; Jai et al., 2020).

A well-developed honest character can make children a godly human being and the successor of a nation with noble character. Honest means telling the truth, therefore it is important to stimulate this development. The role of teachers who are creative and serve as guidelines for their students will be very useful. Because good students come from good teachers too. So from conveying learning the teacher must convey something in accordance with the actual situation.

Honesty can also lead the country and the nation towards ideal prosperity, where with high honesty the nation's children can reduce negative negative attitudes. Where justice does not harm and takes away the rights of others (Megawangi, 2004), of course this is very important for early childhood, where children are still egocentric, sometimes like to take things that do not belong to them, with honesty children can act more independent and confess his actions. Distracting children's feelings and thoughts to feel what others are experiencing can melt their hearts (Novriyansah et al., 2017). When a problem occurs, don't immediately intervene with the child, give direct confidence to solve the problem yourself while monitoring directly so that the negative impacts that arise do not occur (Novriyansah et al., 2017).

The role of schools, workplaces, and community homes is very important to be highlighted in character building in children with interests that the public wants on this topic (Duckworth, 2016; Hong, 2014; Widiarti, 2013). Insights about someone in cultivating character have demanded more attention where teachers from the beginning reported children's behavior (Clement \& Bollinger, 2017; Haslip et al., 2019). Character education is not just about the difference between right and wrong, but more about habituation by instilling the value of goodness so that children can act according to these values (Setiardi, 2017).

Character has two negative and positive sides, the role of parents and teachers is the determinant of which character a child will have, so the cultivation of habituation in children is very important, through small things such as saying greetings we have given examples and 
understanding to children that every time they enter, going out, meeting someone needs to say greetings politely. Honest character is one of the characters that must be owned by children, where children can be taught to say something truthfully. Many strategies and methods can be developed, such as through storytelling (Ramdhani et al., 2019) which provides children with advice and moral values that need to be emulated, exemplary (Munawwaroh, 2019), habituation (Batubara, 2015) and provide interesting learning models (Ramdhani \& Yuliastri, 2018).

Modeling is an effort that teachers can do to develop honest character, where the prophets and apostles can be a guide for mankind. Where the prophets and apostles are formed a high honest character. So that they are trusted by many people, especially in trade. Habituation is an activity in which children accustom themselves to speak honestly with both the teacher and their parents, so a teacher must give a warning if the child does not speak honestly (Batubara, 2015). These two strategies are often used by teachers by developing daily activities to develop honest character in children.

Developing children's character is very important because children will face an era that is different from the era we face today, they are expected to be able to survive and avoid everything that makes them fall into things that are prohibited by religion. Character education does not only teach children what is right and what is wrong, but more than that character education instills habits (habituation) about what is good until they understand, are able to feel and are also willing to implement it. through character education is able to bring virtue from within oneself and being able to bring an attitude, values and morals such as honesty in speaking or acting well to themselves, to others and to their god. Thenattitude this will be seen and appear in real action, is good behavior, honesty, responsibility, respect for the rights of others, hard work and so on (Mulyadi et al., 2019).

Every religious teaching teaches individuals to always self-evaluate their mistakes. done, the child must be accustomed to taking risks, challenges, responsibility and punishment for all negative behavior that they do. The development of the child must be given an understanding of a competition (Megawangi, 2004). Seeing other people can create an arrogant attitude and make other people a threat, so it is necessary to get used to respecting the excellence of others. Teachers must also be able to avoid comparing children's behavior, because this can break children's self-confidence and become insecure. The teacher's role is to provide guidance so that children always appreciate the superiority of their friends by 
providing an understanding of the children's weaknesses and strengths. So that children will be able to respect others with honesty in accepting other people's achievements.

The development of the character of honesty in children does not only rely on the role of teachers and schools, but also requires the role of parents and the environment that continues to provide attention and advice on honesty (Ginanjar, 2017). An environment that builds and develops honest character in children must have the courage to give punishment for those who are not honest and reward children who want to be honest. This is important so that children can be honest about their feelings, mistakes, actions or actions. Parents must be able to encourage children so that children can be respected and trusted in the present or adulthood.

\section{CONCLUSIONS AND SUGGESTIONS}

Important to develop and instill honest character in early childhood so that the Indonesian nation in particular can reduce a culture of corruption or dishonesty in actions. Character education is very important by providing habituation for children to always apply virtuous actions so that the nation and state can progress well, honesty as a good character is needed to increase children's piety to God.

Based on the conclusions from the results of the research above, the researchers conveyed the following suggestions, school institutions should make learning programs to develop honest characters in early childhood according to their age development, teachers are expected to always provide habituation and exemplary to develop honest characters in children, in the behavior of children who want to admit mistakes and appreciate the excellence of others, it is very important to examine more deeply and focus on other character values.

\section{ACKNOWLEDGEMENT}

I would like to express my gratitude to those who have helped, contributed thoughts and funds in writing this article. Thank you very much to the PAUD institution for providing the opportunity for time and information related to this research, so that this article can be properly compiled. 


\section{REFERENCES}

Anggraini, W., \& Kuswanto, C. W. (2019). Teknik Ceklist Sebagai Asesmen Perkembangan Sosial Emosional di RA. Al-Athfaal: Jurnal Ilmiah Pendidikan Anak Usia Dini, 2(2), 61-70. https://doi.org/10.24042/ajipaud.v2i2.5248

Anwar, S. (2016). Peran Pendidikan Agama Islam dalam Membentuk Karakter Bangsa. AlTadzkiyyah: Jurnal Pendidikan Islam, 7, 1-13.

Batubara, J. (2015). Pengembangan Karakter Jujur Melalui Pembiasaan. Jurnal Konseling Dan Pendidikan, 3(1), 1. https://doi.org/10.29210/112000

Burhanuddin, H. (2019). Pendidikan Karakter Dalam Perspektif Al Qur'an. Al-Aufa: Jurnal Pendidikan Dan Kajian Keislaman, 1(1), 1-9. https://doi.org/10.36840/alaufa.v1i1.217

Clement, S., \& Bollinger, R. (2017). Accelerating Progress: A New Era of Research on Character Development. Journal of Youth and Adolescence, 46(6), 1240-1245. https://doi.org/10.1007/s10964-017-0681-9

Davidson, C. (2010). Conversations as signifiers: Characters on the margins of morality in the first three novels of Frances Burney. Partial Answers, 8(2), 277-304. https://doi.org/10.1353/pan.0.0181

Duckworth. (2016). Grit: The Power of Passion and Perseverance. NY: Scribner.

Ernawati. (2017). Menumbuhkan nilai Pendidikan Karakter Anak Melalui Dongeng Fabel dalam Pembelajaran. Jurnal Pendidikan Dan Pembelajaran Dasar, 4, 120-133.

Fauzi, F. Y., Arianto, I., \& Solihatin, E. (2013). Peran Guru Pendidikan Pancasila dan Kewarganegaraan dalam Upaya Pembentukan Karakter Peserta Didik. Jurnal Ppkn Unj Online, 1(2013), 2.

Fitri, M., \& Na'imah, N. (2020). Faktor Yang Mempengaruhi Perkembangan Moral Pada Anak Usia Dini. Al-Athfaal: Jurnal Ilmiah Pendidikan Anak Usia Dini, 3(1), 1-15. https://doi.org/10.24042/ajipaud.v3i1.6500

Ginanjar, M. H. (2017). Keseimbangan Peran Orang Tua Dalam Pembentukan Karakter Anak. Edukasi Islami: Jurnal Pendidikan Islam, 2(03), 230-242.

Haslip, M. J., Allen-Handy, A., \& Donaldson, L. (2019). How do Children and Teachers Demonstrate Love, Kindness and Forgiveness? Findings from an Early Childhood Strength-Spotting Intervention. Early Childhood Education Journal, 47(5), 531-547. https://doi.org/10.1007/s10643-019-00951-7

Hong, P. Y. P. (2014). How children succeed: Grit, curiosity, and the hidden power of character, Paul Tough . Qualitative Social Work, 13(3), 438-442. https://doi.org/10.1177/1473325014530940a

Jai, A. J., Rochman, C., \& Nurmila, N. (2020). Peran Pendidikan Agama Islam Dalam Membentuk Karakter Jujur Pada Siswa. Al-Tadzkiyyah: Jurnal Pendidikan Islam, 10(2), 257-264. https://doi.org/10.24042/atjpi.v10i2.4781

Juanda, J. (2019). Pendidikan Karakter Anak Usia Dini melalui Sastra Klasik Fabel Versi Daring. Jurnal Obsesi : Jurnal Pendidikan Anak Usia Dini, 3(1), 39. https://doi.org/10.31004/obsesi.v3i1.126

Kesuma, D. (2011). Pendidikan Karakter Kajian Teori dan Praktik di Sekolah. Rosda Karya. Kim, S., Choe, I., \& Kaufman, J. C. (2019). The development and evaluation of the effect of creative problem-solving program on young children's creativity and character. Thinking Skills and Creativity, 33(August 2018), 100590.

https://doi.org/10.1016/j.tsc.2019.100590

Komara, E. (2018). Penguatan Pendidikan Karakter dan Pembelajaran Abad 21. SIPATAHOENAN: South-East Asian Journal for Youth, Sports \& Health Education, 
$4(1), 17-26$.

Lerner, R. M. (2018). Character development among youth: Linking lives in time and place. International Journal of Behavioral Development, 42(2), 267-277. https://doi.org/10.1177/0165025417711057

Megawangi, R. (2004). Pendidikan Karakter: Solusi yang Tepat untuk Membangun Bangsa. Yayasan Warisan Indonesia.

Mulyadi, D., Sapriya, S., \& Rahmat, R. (2019). Kajian tentang Penumbuhan Karakter Jujur Peserta Didik sebagai Upaya Pengembangan Dimensi Budaya Kewarganegaraan (Civic Culture) di SMA Alfa Centauri Bandung. MODELING: Jurnal Program Studi PGMI, 6(2), 220-232. https://doi.org/10.36835/modeling.v6i2.471

Mulyasa, H. (2013). Manajemen Pendidikan Karakter. Bumi Aksara.

Munawwaroh, A. (2019). Keteladanan Sebagai Metode Pendidikan Karakter. Jurnal Penelitian Pendidikan Islam, 7(2), 141. https://doi.org/10.36667/jppi.v7i2.363

Novriyansah, A., Kurniah, N., \& Suprapti, A. (2017). Studi Tentang Perkembangan Karakter Jujur Pada Anak Usia Dini. Journal of Physics A: Mathematical and Theoretical, 2(1), 14-22. https://doi.org/10.1088/1751-8113/44/8/085201

Nurgiansah, T. H. (2021). Pendidikan Pancasila Sebagai Upaya MembentukKarakter Jujur. Jurnal Pendidikan Kewarganegaraan, 9(1), 33-41.

Prasanti, D., \& Fitrianti, D. R. (2018). Pembentukan Karakter Anak Usia Dini: Keluarga, Sekolah, Dan Komunitas. Pembentukan Anak Usia Dini : Keluarga, Sekolah, Dan Komunitas, 2(1), 15.

Purwanti, D. (2017). Pendidikan Karakter Peduli Lingkungan Dan Implementasinya. DWIJA CENDEKIA: Jurnal Riset Pedagogik, 1(2), 14-20. https://doi.org/10.20961/jdc.v1i2.17622

Ramdhani, S., \& Yuliastri, N. A. (2018). Model Pembelajaran Tematik Integratif Untuk Membentuk Karakter Jujur Anak Usia 5-6 Tahun. Jurnal Pelita Paud, 2(2), 149-150.

Ramdhani, S., Yuliastri, N. A., Sari, S. D., \& Hasriah, S. (2019). Penanaman Nilai-Nilai Karakter melalui Kegiatan Storytelling dengan Menggunakan Cerita Rakyat Sasak pada Anak Usia Dini. Jurnal Obsesi : Jurnal Pendidikan Anak Usia Dini, 3(1), 153. https://doi.org/10.31004/obsesi.v3i1.108

Rochmawati, N. (2018). Peran Guru dan Orang Tua Membentuk Karakter Jujur Pada Anak. Jurnal Al-Fikri: Jurnal Studi Dan Penelitian Pendidikan Islam, 1(2), 1-12.

Rudyanto, H. E. (2016). Model Discovery Learning Dengan Pendekatan Saintifik Bermuatan Karakter Untuk Meningkatkan Kemampuan Berpikir Kreatif. Premiere Educandum : Jurnal Pendidikan Dasar Dan Pembelajaran, 4(01), 41-48. https://doi.org/10.25273/pe.v4i01.305

Sayer, I. M., Kristiawan, M., \& Agustina, M. (2018). Fairy Tale as a Medium for Children's Character Cooperation Building. Al-Ta Lim Journal, 25(2), 108-116. https://doi.org/10.15548/jt.v25i2.458

Schaps, E., \& Lewis, C. (2019). Eleven Principles of Effective Character Education. January 1996.

Setiardi, D. (2017). Keluarga Sebagai Sumber Pendidikan Karakter Bagi Anak. Tarbawi : Jurnal Pendidikan Islam, 14(2). https://doi.org/10.34001/tarbawi.v14i2.619

Setiawati, L. (2015). Pembentukan Karakter Siswa Melalui Pembelajaran Bahasa Dan Sastra Indonesia. Jurnal Pendidikan, 16(1), 65-73. https://doi.org/10.33830/jp.v16i1.336.2015

Setyaningrum, E. A. (2017). The Implementation of the Characters Education to the Early Childhood Based. Journal Belia, 6(2), 136-142. 
Silahuddin. (2017). Urgensi Membangun Karakter Anak Sejak Usia Dini. Fakultas Tarbiyah Dan Keguruan UIN Ar-Raniry, 3(2), 18-41.

Sri Wening. (2012). The nation's Character Building Through Value Education. Jurnal Pendidikan Karakter, 1(2), 55-66.

Sugiyono. (2013). Metode Penelitian Kombinasi. CV Alfabeta.

Surya, Y. F. (2017). Penggunaan Model Pembelajaran Pendidikan Karakter Abad 21 pada Anak Usia DIni. Jurnal Obsesi : Jurnal Pendidikan Anak Usia Dini, 1(1), 52-61. https://doi.org/https://.doi.org/10.31004/obsesi.v1i1.30

Tadjuddin, N. (2018). Pendidikan Moral Anak Usia Dini Dalam Pandangan Psikologi, Pedagogik, dan Agama. Al-Athfaal: Jurnal Ilmiah Pendidikan Anak Usia Dini, 1(1), 100-116. https://doi.org/10.24042/ajipaud.v1i1.3386

Wagner, L. (2019). Good Character Is What We Look for in a Friend: Character Strengths Are Positively Related to Peer Acceptance and Friendship Quality in Early Adolescents. Journal of Early Adolescence, 39(6), 864-903. https://doi.org/10.1177/0272431618791286

Wang, J., Ferris, K. A., Hershberg, R. M., \& Lerner, R. M. (2015). Developmental Trajectories of Youth Character: A Five-Wave Longitudinal Study of Cub Scouts and Non-Scout Boys. Journal of Youth and Adolescence, 44(12), 2359-2373. https://doi.org/10.1007/s10964-015-0340-y

Waryanti, E. (2015). Pembelajaran sastra berbasis karakter. Jurnal Buana Bastra, 2(2), 156164.

Widiarti, P. W. (2013). Pendidikan Karakter Berbasis Empati Pada Anak-Anak Usia SD. INFORMASI, 39(2). https://doi.org/10.21831/informasi.v0i2.4446

Yaumi, M. (2014). Pendidikan Karakter: Landasan, Pilar, dan Implementasi. Grip Prenadamedia.

Zigon, J. (2007). Moral breakdown and anthropology of moralities. Anthropological Theory, $7(2), 131-150$. 